\title{
„i / ta wielka łapka / na ludzi"1 o podmiocie w poezji Ewy Lipskiej
}

\begin{abstract}
Marciniak Paweł, "i / ta wielka łapka / na ludzi” - o podmiocie w poezji Ewy Lipskiej [", and / this large / human flap" - The Subject in the Poetry of Ewa Lipska]. "Przestrzenie Teorii" 35. Poznań 2021, Adam Mickiewicz University Press, pp. 83-101. ISSN 1644-6763. DOI 10.14746/ pt.2021.35.3.

The article concerns the idea of the subject's evolution in the poetry of Ewa Lipska. The article presents the unexplored path of subjectivity's development in selected poems by this Cracovian poet. The main research concept regards the interpretation of particular poems from the perspective of current philosophical problems, connected with posthumanism, which is understood here as the ability to go beyond the bounds of humanism, a revision of previous humanistic assumptions. The essential change of direction in the reception of Ewa Lipska's writings could be perceived as a result of the interpretation contained in this article.
\end{abstract}

KEYWORDS: posthumanism, Ewa Lipska, poetic subject, the revision of humanism

Kto tu jest człowiek - a kto człowiek? ${ }^{2}$

Ewa Lipska, Zabawa

\section{Walka o programowość ${ }^{3}$}

W krytycznoliterackiej recepcji twórczości Ewy Lipskiej zaistniał niegdyś spór ${ }^{4}$ toczący się wokół kwestii wiersza założycielskiego, który w sposób programowy wyznaczałby dalszy kierunek rozwoju poezji autorki Nie domykajmy drzwi. Niektórzy badacze, jak na przykład Anna Legeżyńska, wskazywali na istotę wiersza $M y$, stanowiącego diagnozę pokolenia urodzonego tuż po II woj-

${ }^{1}$ E. Lipska, Testament (I), [w:] Nowy wybór wierszy, Kraków 2020, s. 41.

${ }^{2}$ E. Lipska, Zabawa, [w:] Wiersze, Warszawa 1967, s. 12.

${ }^{3}$ Tytuł artykułu odwołuje się do pierwszej części (,Mogę kontra My”) wstępu Krzysztofa Lisowskiego - Historie osobiste (o liryce Ewy Lipskiej), otwierajacego wydany w 1996 roku wybór wierszy poetki, Wspólnicy zielonego wiatraczka: E. Lipska, Wspólnicy zielonego wiatraczka, Kraków 1996. W kolejnej edycji tego zbioru, wznowionego w 2007 roku, nie przedrukowano już tekstu autorstwa Lisowskiego. Por. E. Lipska, Wspólnicy zielonego wiatraczka, Warszawa 2007.

${ }^{4}$ Przypomina o nim także Aneta Piech-Klikowicz, analizując kategorię wyobraźni w kreacji podmiotu poetyckiego wierszy Ewy Lipskiej. Zob. A. Piech-Klikowicz, „Patrzymy sobie w oczy...” O twórczości Ewy Lipskiej, Kraków 2013, s. 201-207. 
nie światowej. Konkurencyjną propozycję przedstawił we wstępie do Wspólników zielonego wiatraczka Krzysztof Lisowski, pochylając się nad tekstem Moge który - zdaniem krytyka - „z perspektywy następnych, pełniejszych odczytań tej twórczości - zapowiada właściwa Lipska, jej utwory wciąż pełne inwencji, wyobraźni, zaskakujących paradoksów, puent, zadziwiających metafor" ". Biorąc pod uwagę opowiedzenie się Lipskiej po stronie indywidualności poetyckiej (stopniowe odcinanie się od Nowej Fali) oraz konsekwentnie rozwijaną poetykę prowadzącą do tekstowego ascetyzmu spod znaku poezji intelektualnej, trudno dziś nie przyznać Lisowskiemu racji. Symbolicznym gestem o charakterze detronizującym okazał się ponadto wymowny brak wiersza My w pracach nad układem Wspólników zielonego wiatraczka.

Od momentu ukazania się przywołanego wyboru minęły już przeszło dwie dekady. W tym czasie Lipska opublikowała około 20 książek poetyckich, pośród których, oprócz nowych wierszy, odnaleźć można prozę, piosenki czy kolejne antologie (sporadycznie wydawane w formie dwujęzycznej6). Ponowne spojrzenie na dzieło krakowskiej autorki umożliwiłoby zatem przesunięcie interpretacyjnych wektorów. Pomysł Lisowskiego pozwolił ostatecznie na zmianę toku lektury. Idzie tu o sukcesywne odchodzenie od zagadnień powiązanych z doświadczeniem zbiorowości $(M y)$ na korzyść dynamicznie kształtującej się jednostki (Mogę), a co się z tym wiąże - na rzecz Człowieka, uznawanego do tej pory za najważniejszego bohatera wierszy Lipskiej.

Moja propozycja badawcza wybiega o krok dalej, koncentrując się na utworach, które w znacznym stopniu podważają rangę bycia człowiekiem we współczesnym świecie i skupiają się na - szeroko rozumianych - nie-ludzkich $^{7}$ aspektach egzystencji. Wiersz, który mógłby symbolicznie patronować zarysowanej tu linii interpretacyjnej, winien pozostać miejscem przecięcia się pierwiastka zbiorowego (dostrzeżenie innych obszarów życia) z pierwiastkiem jednostkowym (demontaż silnego ludzkiego podmiotu). W moim odczuciu za adekwatny przykład uznać można w tym wypadku wiersz Jesteśmy, który w samym już tytule osłabia opozycję ukonstytuowaną niegdyśs w wyniku walki My kontra Moge.

${ }^{5}$ K. Lisowski, Historie osobiste (o liryce Ewy Lipskiej), [w:] E. Lipska, Wspólnicy zielonego wiatraczka, Kraków 1996, s. 6.

${ }^{6}$ Mowa tu o pozycjach z roku 1998, 2000, 2007 czy 2017: E. Lipska, Życie zastępcze, Kraków 1998 (wydawnictwo polsko-niemieckie); tejże, Białe truskawki, Kraków 2000 (wydawnictwo polsko-angielskie); tejże, Miasteczko świat, Kraków 2007 (wydawnictwo polsko-rosyjskie); tejże, Pęknięte oko czasu (droga Pani Schubert...) / L'œil fêlé du temps (chère madame Schubert...), Kraków-Budapeszt 2017.

${ }^{7}$ Pisownię terminu „nie-ludzkie” przyjmuję w mojej pracy za Monika Bakke, która odwołuje się w tej kwestii do rozważań Jana Wawrzyniaka (konkretnie do pracy Teoretyczne podstawy neonaturalistycznej bioetyki środowiskowej, Poznań 2000). Zob. M. Bakke, Bio-transfiguracje. Sztuka i estetyka posthumanizmu, Poznań 2010, s. 8. 


\section{Osłabiony humanizm}

Tekst Jesteśmy, zajmujący chronologicznie czwartą pozycję w Wierszach, poprzedzony został utworem Spotkanie z Ziemia, który również wpisuje się $\mathrm{w}$ tematykę rozwijaną w niniejszym artykule. Chodzi tu rzecz jasna o przekierowywanie uwagi na nie-ludzkie obszary życia. Obydwa wiersze stanowia przeciwwage dla - bez wątpienia antropocentrycznych - My oraz Mogę, otwierających debiutancki tom Lipskiej. W tym kontekście przywołany poniżej utwór Jesteśmy sytuowałby się wprawdzie na marginesie rozważań wokół sporu o programowość, jednak wraz ze Spotkaniem z Ziemia ustala punkt wyjścia dla lektury konstruowanej na podstawie aktualnych zagadnień filozoficznych (myślę tu zwłaszcza o szeroko rozumianej filozofii posthumanizmu, obejmujacej „tak kluczowe zagadnienia, jak uprzywilejowany status ludzkiego gatunku czy stosunek do technologii" ${ }^{8}$ ), pozwalając na istotną reorientację (z ludzkiego na nie-ludzkie) odbioru tekstów poetyckich Ewy Lipskiej:

Ani z pewników. Ani z Biblii świętej.

Ani z historii. Ani z ziemi Ziemi.

Ani z poległych. Ani z tych mniej więcej.

I ani z próżni. I ani z kamieni.

Zbyteczne myśleć o świata genezach.

Rozbierać ciało na cyfry i wieki.

Z braku założeń nie liczmy na tezy.

Biegniemy naprzód ciagle stojąc w miejscu.

Jesteśmy z wyobraźni. Przypadku. I słowa

które słowem się stały. I ciałem. I światem.

Nasze kroki - to czasu jest pierwsza połowa.

Kroki czasem przystaja. I czas staje czasem.

Chcesz wiedzieć to co będzie. I to co już było.

Zejdź z wiedzy nieumyślnej. I z umyślnych twierdzeń.

Ani wstecz ani naprzód nic się nie zmieniło.

I to co masz po prawej masz po lewej ręce ${ }^{9}$.

Interesujący wydaje się już tytuł - Jesteśmy - który wybrzmiewa w oznajmujący, niemal deklaratywny sposób. Poezja Lipskiej, nawet w początko-

${ }^{8}$ M. Bakke, dz. cyt., s. 18.

${ }^{9}$ E. Lipska, Jesteśmy, [w:] Wiersze..., s. 9. Od tej chwili wszelkie nieoznakowane cytaty pochodzą właśnie z tego utworu. 
wej fazie rozwoju, nie przywykła jednak do udzielania prostych odpowiedzi. Pierwsza strofa cytowanego tekstu nie sugeruje w zasadzie żadnego rozwiąania. Chaos poznawczy polega w tym wypadku na konsekwentnym odrzucaniu możliwych koncepcji związanych z pojawieniem się życia na Ziemi. Nieistotne wydaja się fakty (,Ani z pewników”), hipotezy naukowe (,Ani z tych mniej więcej”) oraz wykładnie religijne („Ani z Biblii świętej”).

Podmiot - przemawiający zarówno w imieniu, jak i do gatunku ludzkiego - próbuje zatem zrozumieć początek ewolucji poprzez negację, wprowadzając poczucie ontologicznego niepokoju potęgowane w dalszych partiach utworu. W tym aspekcie jako fundamentalna dla przesłania wiersza jawi się jego druga strofa o charakterze intonacyjno-zdaniowym, w której celowa rezygnacja $\mathrm{z}$ rymów ${ }^{10} \mathrm{w}$ poszczególnych klauzulach uwydatnia każdy wers. Omawiany fragment zdaje mi się wystarczająco istotny, by przytoczyć go ponownie: „Zbyteczne myśleć o świata genezach. / Rozbierać ciało na cyfry i wieki. / Z braku założeń nie liczmy na tezy. / Biegniemy naprzód ciągle stojąc w miejscu”. W przywołanym cytacie „ja” liryczne nawołuje do porzucenia wszelkich starań mających na celu wyjaśnienie przyczyn powstania kuli ziemskiej (,zbyteczne myśleć o świata genezach”) oraz zalążków ludzkiego życia (,rozbierać ciało na cyfry i wieki”). Wyraźnie zatem daje tu o sobie znać teza o podważonym humanizmie, żywiołowo komentowana przez niektórych badaczy dzisiejszych teorii posthumanistycznych. Monika Bakke wymienia w tym kontekście takie nazwiska, jak Nikolas Rose czy Cary Wolfe, dla których posthumanizm nie wiąże się z odrzuceniem, lecz zakwestionowaniem dotychczasowych założeń humanistycznych ${ }^{11}$. Analogiczną postawę przyjmuje podmiot utworu Zawracajmy z Drugiego zbioru wierszy: „Ktoś wielce nas oszukał. / Tam nie ma żadnych praw. Tam wiatr jest nieruchomy. / Koła są błędne. Zdradziła nas nauka. / I głuchą jest przyrodnia siostra dialektyki" ${ }^{12}$. Przytoczony ustęp - ostatnie cztery wersy pierwszej strofy - świadczy o głębokim rozczarowaniu „ja” lirycznego. Poczucie przygnębienia (,ktoś wielce nas oszukał”) wynika być może z przesadnej wiary w możliwości współczesnej technologii (,zdradziła nas nauka”), które prowadzą do rozmaitych dylematów moralnych (,tam nie ma żadnych praw”). W wątpliwość podana zostaje więc efektywność nurtu transhumani-

${ }^{10}$ Warto wspomnieć także o rymie niedokładnym (niemal zatartym) - „genezach-tezy”. Naukowość języka okazuje się tu zatem połączona współbrzmieniem, pozwalającym zachować $\mathrm{w}$ tej strofie melodię całego wiersza.

${ }^{11}$ M. Bakke, dz. cyt., s. 7-10. Poznańska badaczka przywołuje tu głównie dwie prace: N. Rose, The politics of Life Itself. Biomedicine, Power, and Subjectivity in the Twenty-First Century, Princeton University Press 2007; C. Wolfe, What Is Posthumanism?, London-Minneapolis, University of Minnesota Press 2010.

${ }^{12}$ E. Lipska, Zawracajmy, [w:] Drugi zbiór wierszy, Warszawa 1970, s. 36. 
stycznego $^{13}$, a echa tej deziluzji pobrzmiewają jeszcze w drugiej (i zarazem przedostatniej) strofie utworu: „Tam samotność najbogatszym państwem. / Tam nic nie ma. Nawet nie ma muzyki. / I nadziei która budzi nas o świcie / tak codziennie przedłużając nasze życie" ${ }^{14}$. Cytowane wersy obrazują piekło nadchodzącej codzienności. Do zastosowania metaforyki infernalnej skłania przede wszystkim wers „Nawet nie ma muzyki”. Biorąc pod uwagę istotna pozycję, jaką zajmuje muzyka - podkreślam: muzyka, nie piosenka - w twórczości Ewy Lipskiej, przestrzeń pozbawiona dźwięków musi w jakimkolwiek stopniu nawiązywać do przestrzeni piekielnej. W tym kontekście ironiczne porównanie samotności do „najbogatszego państwa” sugeruje, że izolacja człowieka - będąca przecież punktem dojścia - stanowi największe źródło jego cierpień. Omawiany fragment wydaje się wówczas zaskakująco aktualny w zestawieniu ze współczesnymi antyutopiami transhumanistycznymi, kreującymi wizje osamotnionych i rzekomo nieustannie szczęśliwych ludzi. Myślę tu na przykład o jednej z głośnych powieści Michela Houellebecqa Możliwość wyspy, a zwłaszcza o fragmentach, w których głos narracji należy do postludzi - Daniela 24 oraz Daniela 25 - dla których przekleństwem okazuje się doświadczenie obcości i wszechobecnego perfekcjonizmu ${ }^{15}$.

Aneta Piech-Klikowicz odczytuje wiersz Zawracajmy przez pryzmat kategorii estetycznych (wzrok zapewniający jednostce dostęp do niedostępnego) oraz etycznych (konsekwencją objawienia okazuje się odpowiedzialność za resztę ludzkości) ${ }^{16}$. Decydujaccy wpływ na lekturę badaczki ma zapewne sam początek utworu: „Wybiegłam naprzód. Na wzrok najwyższy się wspięłam. / I zobaczyłam: przede mna pokolenia / szły do mnie całym swym czasem" ${ }^{17}$. W takim wypadku „ja” liryczne przyjmuje cechy „ratownika”, pragnac „zaopiekować się ludźmi do końca"18. Nie za bardzo wiadomo tylko, na czym miałaby polegać ewentualna pomoc, a także kiedy ów „koniec” nastapi.

Nie ma powodu, aby rozpatrywać tekst Lipskiej jedynie w przestrzeni językowej. Przeciwnie, dostrzec w nim można realne odbicie lęków oraz niepokojów drugiej połowy XX wieku, a symboliczne uniesienie podmiotu poza sferę empiryczną (niemożliwe przecież w realnym doświadczeniu ${ }^{19}$ )

${ }^{13}$ Kwestia postępu technologicznego uchodzi w moim odczuciu za jeden z najważniejszych - i jednocześnie najbardziej niedoczytanych przez krytykę - wątków w poezji Ewy Lipskiej.

${ }^{14}$ E. Lipska, Zawracajmy..., s. 36.

${ }^{15}$ M. Houellebecq, Możliwość wyspy, Warszawa 2015.

${ }^{16}$ A. Piech-Klikowicz, dz. cyt., s. 181-182.

${ }^{17}$ E. Lipska, Zawracajmy..., s. 36.

${ }^{18}$ A. Piech-Klikowicz, dz. cyt., s. 182.

${ }^{19} \mathrm{Nie}$ oznacza to anulowania samej potrzeby takiego uniesienia, która rodzi się z pragnienia zastapienia czasu fizycznego czasem mitycznym. Pisał o tym Leszek Kołakowski: L. Kołakowski, Obecność mitu, Kraków 1981. Chodzi tu zwłaszcza o dwa pierwsze rozdziały. 
traktować należy raczej za wyraz kształtowania się samoświadomości, aniżeli heroiczną decyzję o zbawieniu ludzkości. Kwestię etyczną - sugerowaną przez alarmujący (ostrzegawczy) wydźwięk tytułu tego tekstu (Zawracajmy) - rozpatrywałbym wówczas w perspektywie egzystencjalistycznej, określonej przez Sartre’a jako splot odpowiedzialności za innych ludzi oraz niepokoju rodzącego się na skutek podejmowanych decyzji ${ }^{20}$.

Znajdująca się w utworze krytyka rozwoju technologicznego (,postęp cyfr" $\left.{ }^{21}\right)$, który nie zważa na obowiązującą etykę, może destabilizować humanistyczne założenia. Wszelki opór wobec ulepszania rzeczywistości oraz samego człowieka osłabiałby zatem granice ustalone przez dotychczasowe dziedzictwo kulturowe. Rzecz dotyczy także analizowanego wcześniej wiersza Jesteśmy, w którym podmiot wyraża głęboką nieufność względem postawy antropocentrycznej: „Zejdź z wiedzy nieumyślnej. I z umyślnych twierdzeń. / Ani wstecz ani naprzód nic się nie zmieniło". Przemyślenie zastanego dorobku intelektualnego (,wiedza nieumyślna”, „umyślne twierdzenia”) zagwarantowałoby więc wypracowanie nowych wartości.

Anonsowane wcześniej pytanie o genezę postawione w utworze Jesteśmy nie pozostaje przemilczane. Podmiot udziela na nie odpowiedzi w wersach otwierających trzecią strofę tekstu: „Jesteśmy z wyobraźni. Przypadku. I słowa / które słowem się stały. I ciałem. I światem". W tym miejscu wiersza zmianie ulega rytmika. Przejście z regularnego jedenastozgłoskowca na regularny trzynastozgłoskowiec w wyraźny sposób spowalnia tempo utworu, podkreślając tym samym wagę wypowiadanych słów, jak gdyby podmiot przygotowywał odbiorce na istotny moment udzielenia odpowiedzi. W trakcie analizy przytoczonych wersów automatycznie przypominają się uwagi Krzysztofa Lisowskiego na temat wiersza Moge w kontekście „twórczej aneksji niezamierzonych obszarów indywidualnej wy obraźni, tej cechy ludzkiej umysłowości, która daje poczucie wolności bez warunków, swobody nawet wbrew egzystencjalnym, fizycznym czy politycznym ograniczeniom" ${ }^{22}$. Jednakże „wyobraźnia” w tekście Jesteśmy nie stanowi jedynie przykładu kształtujacej się dopiero poetyki, nie jest li tylko autotematycznym potwierdzeniem zarysowującej się programowości. Sprzężenie zagadnienia genezy gatunku ludzkiego z wyobraźniowym konstruktem otwiera pole do dyskusji o symbolicznym kresie człowieka ${ }^{23}$. Proponowana przeze mnie linia

${ }^{20}$ Zob. J.-P. Sartre, Problem bytu i nicości. Egzystencjalizm jest humanizmem, Warszawa 2001 , s. 137.

${ }^{21}$ E. Lipska, Zawracajmy..., s. 36.

${ }^{22}$ K. Lisowski, dz. cyt., s. 6 (podkreślenie autora). W cytowanym przeze mnie wydaniu znajduje się zapis „ograniczeniem” - uznaję go za błąd w druku.

${ }^{23}$ Warto odnotować, że wydanie Wierszy (1967) zbiega się poniekąd z pierwszymi edycjami kanonicznych pozycji poruszających problem „śmierci człowieka”. Mam tu na myśli 
interpretacyjna sytuowałaby się zatem $\mathrm{w}$ granicach antyhumanizmu oraz posthumanizmu ${ }^{24}$. Analizowane w tej pracy wiersze Ewy Lipskiej w dużej mierze odwołują się do bodaj najważniejszego punktu wspólnego przywołanych tu prądów myślowych - do osłabionego podmiotu humanistycznego.

\section{Przepracowywanie humanizmu}

Jedną z istotnych konsekwencji, jakie niesie ze sobą rewizja postulatów humanistycznych, może okazać się stan świadomości określony przez Neila Badmingtona jako „trauma humanizmu”, warunkująca „praktyki krytyczne nie tyle wobec humanizmu, czyli z pozycji wewnętrznej, ile przede wszystkim dokonujące się wewnątrz humanizmu"25. W konsekwencji Badmington opiera swoje rozumienie posthumanizmu na Lyotardowskiej koncepcji „przepisania nowożytności” ${ }^{26}$ „ „Chcę zapożyczyć zapożyczenie Lyotarda, aby przenieść je [...] na obszar posthumanizmu"27. W przywołanym stwierdzeniu za kluczowe uznać wypada owo podwójne „zapożyczenie”. Lyotard, próbując uchwycić istotę postmodernizmu, odwołuje się między innymi do badań Freuda. Psychoanalityczne zagadnienie przepracowywania (working-through) traumy przez pacjenta posłużyło francuskiemu filozofowi jako analogia w zmaganiach z nowożytnościa, na co wskazuje także Badmington: „Modernizm oraz postmodernizm, należy to podkreślić, nie powinny być postrzegane jako wyłącznie odrębne całości: postmodernizm jest przepisywaniem modernizmu”28. Postmodernistyczne „przepisywanie” (rewriting) stanowi zatem odpowiednik „przepracowywania” - jest zmaganiem z moder-

Stowa i rzeczy: Archeologię nauk humanistycznych Foucaulta (1966) oraz Śmierć autora Barthes'a (1967). Prace francuskich filozofów stosunkowo późno przeszczepiono na grunt polskiej myśli humanistycznej, jednakże wybrane wiersze Lipskiej silnie korespondują z głównymi założeniami czołowych przedstawicieli antyhumanizmu.

${ }^{24} \mathrm{O}$ typologii stanowisk filozoficznych z zakresu szeroko rozumianego posthumanizmu pisała Francesca Ferrando: F. Ferrando, Posthumanism, Transhumanism, Antihumanism, Metahumanism, and New Materialisms Differences and Relations, „Existenz. An International Journal in Philosophy, Religion, Politics, and the Arts" 2013, Volume 8, No 2, Fall, s. 26-32.

${ }^{25}$ M. Bakke, dz. cyt., s. 19.

${ }^{26}$ J.-F. Lyotard, Przepisać nowożytność, [w:] Postmodernizm a filozofia. Wybór tekstów, red. S. Czerniak, A. Szahaj, Warszawa 1996, s. 45-58.

${ }^{27}$ N. Badmington, Theorizing Posthumanism, „Cultural Critique” 2003, nr 53, s. 21. W wersji anglojęzycznej: „I want to borrow Lyotard's borrowing, to carry it [...] to the space of posthumanism" - tłum. moje. Odtąd wszelkie nieopisane tłumaczenia w tym artykule pozostają mojego autorstwa.

${ }^{28}$ N. Badmington, dz. cyt., s. 20. W wersji anglojęzycznej: „Modernity and postmodernity, that is to say, should not be thought of as entirely distinct entities: postmodernity is the rewriting of modernity". 
nizmem, polegającym na kwestionowaniu niektórych jego założeń, i właśnie ten potencjał krytyczny określa sposób funkcjonowania posthumanizmu w propozycji Badmingtona. Interesujący wydaje się więc prefiks „post-”, który „nie oznacza (i, co więcej, nie może oznaczać) całkowitego zerwania z dziedzictwem humanizmu” 29 . „Przepisywanie” w rozważaniach Lyotarda polega nie tyle na rozpoczynaniu czegoś od nowa, ile na przeformułowywaniu i odkrywaniu czegoś na nowo ${ }^{30}$.

Powyższa refleksja na temat przepracowywania humanizmu pomaga skonstruować ramy interpretacyjne, w których z powodzeniem usytuować można, pochodzący także z Wierszy, utwór Przyszłość:

\author{
Wynajęłam sobie przyszłość \\ i już od jutra muszę się wprowadzić \\ zmienić zamek po poprzednim lokatorze. \\ Muszę sprawić sobie nowy krajobraz \\ lustro i półkę na książki \\ żeby móc pisać i rozpoczaćc $c^{31}$ \\ życie samodzielne \\ w pewnej odosobnionej dzielnicy biosfery \\ do której nie dochodzą toasty \\ weselne urodzinowe i pogrzebowe. \\ Muszę sprawić sobie nowy krajobraz. \\ To kosztowna rzecz ${ }^{32}$.
}

W cytowanym tekście zasadniczymi terminami wydają się „przyszłość”, „krajobraz” oraz „biosfera”. Ostatnie z wyróżnionych pojęć stanowi jeden z fundamentów współczesnego myślenia o ludzkości. Uściślając, chodzi tu o reinterpretację statusu człowieczeństwa w zetknięciu z innymi formami życia na naszej planecie, a dokładniej - o detronizację, decentrację człowieka, który staje się jedna z wielu istot żywych: ,jest nieuprzywilejowanym elementem biosfery”33. W wierszu Lipskiej „biosferę” opisuje się jako „pewną odosobnioną dzielnicę”. Ekosystem ma więc atrybuty mieszkalne

${ }^{29}$ Tamże, s. 21. W wersji anglojęzycznej: „does not (and, moreover, cannot) mark or make an absolute break from the legacy of humanism".

${ }^{30}$ Zob. J.-F. Lyotard, dz. cyt., s. 48.

${ }^{31} \mathrm{~W}$ wersji tego tekstu zamieszczonej w Wierszach (chodzi o wydanie cytowane w tym tekście) można natknać się na zapis „rozpocząc. Nie uważam, aby był to celowy zabieg poetycki. Drobną literówkę uznaję zatem za błąd w druku i w artykule decyduję się na wybór słowa „rozpoczaćc”.

${ }^{32}$ E. Lipska, Przyszłość, [w:] Wiersze..., s. 22.

${ }^{33}$ P. Czapliński, J.B. Bednarek, D. Gostyński, Literatura i jej natury, Poznań 2017, s. 177 (podkreślenie autorów). W przytoczonym cytacie autorzy powołują się na pracę Julii 
(,dzielnica”), kojarzone najczęściej z większymi miastami. Warto także zwrócić uwagę na obecny w tym wersie epitet - „odosobnionej” nie wskazuje w tym wypadku na samotność, lecz na obszar miasta (osiedla mieszkaniowe buduje się zazwyczaj na obrzeżach aglomeracji). Przywołany tu sposób obrazowania odzwierciedla niejako faktyczny stan badań w drugiej połowie XX wieku, dotyczący wykładni pojęcia biosfery, które „odnosiło się [...] nie tylko do naturalnego otoczenia Ziemi; było ono też inspiracją dla wielu architektów, inżynierów i artystów, którzy poszukiwali form przeprojektowywania relacji człowiek - przestrzeń" ${ }^{34}$. Niemożliwe stało się zatem rozpatrywanie ludzkiego istnienia w oderwaniu od dopełniającego je otoczenia.

Omawiany koncept nie stanowi jednorazowego przypadku i - podobnie jak wiele innych motywów z Wierszy ${ }^{35}$ - powraca w późniejszych tekstach Lipskiej $^{36}$. Najwyrazistszym przykładem byłaby tu zapewne chwytliwa metafora z nominowanego w 2004 roku do Nagrody Literackiej „Nike” ${ }^{37}$ zbioru Ja. Mam tu na myśli tytuł jednego z utworów, Miasteczko Świat ${ }^{38}$, w którym podmiot zmaga się z pamięcia (odzywa się zatem echo Freudowskiego „przepracowywania"). W swojej twórczości Lipska sukcesywnie dąży do minimalizmu formalnego ${ }^{39}$, a przywołana przeze mnie krótka fraza - „miasteczko Świat” - z powodzeniem oddaje przynajmniej część przesłania omawianego wcześniej konceptualnego wiersza.

Fiedorczuk, Cyborg w ogrodzie: J. Fiedorczuk, Cyborg w ogrodzie. Wprowadzenie do ekokrytyki, Gdańsk 2015.

${ }^{34}$ A. Jelewska, Ekotopie: ekspansja technokultury, Poznań 2014, s. 24.

${ }^{35} \mathrm{Na}$ kwestię powtarzalności motywów w twórczości Ewy Lipskiej wskazywało wielu badaczy. Można tu wspomnieć chociażby Krzysztofa Skibskiego: „Od początku także zarysowują się ślady (tropionych później w tekstach komentujących twórczość Lipskiej) motywów i historii przewodnich”. Zob. K. Skibski, Antropologia wierszem. Język poetycki Ewy Lipskiej, Poznań 2008, s. 23.

${ }^{36}$ Moje spostrzeżenie koresponduje z tezą Skibskiego, który określił Wiersze jako „książkę-ofertę wystosowaną przez poetkę do przyszłego czytelnika. Wszystkie późniejsze cechy charakterystyczne, stałe i konstytutywne dla dalszych dokonań twórczych mają swoje zarzewie, swoją syntetyczną antycypację właśnie w Wierszach". Zob. K. Skibski, dz. cyt., s. 21.

${ }^{37}$ Tom Lipskiej znalazł się w finałowej siódemce, a laureatem został ostatecznie Wojciech Kuczok za powieść Gnój. Krakowska poetka została nominowana do tej samej nagrody w roku 2018 (również finałowa siódemka) za zbiór wierszy zatytułowany Pamięć operacyjna. Zwycięzcą okazał się tym razem Marcin Wicha, autor eseju Rzeczy, których nie wyrzucitem.

${ }^{38}$ E. Lipska, Miasteczko Świat, w: Ja, Kraków 2003, s. 17.

${ }^{39}$ Ostatnio zwrócił na to uwagę Janusz Drzewucki, pisząc na łamach „Twórczości”: „[...] liryka Ewy Lipskiej w XXI wieku podlega nieustannej kondensacji i lapidaryzacji. Redukcja przymiotnika i czasownika na rzecz rzeczownika, a także uprzywilejowana rola równoważnika zdań - to po pierwsze, a po drugie - coraz silniejsza funkcja obrazu, metafory, bywa, że tzw. śmiałej metafory”. Zob. J. Drzewucki, Między intelektem a wyobraźniq, „Twórczość” 2017, nr 10 (863), s. 110-111. 
W utworze Przyszłość pojawia się zatem szansa na aktualizację problematyki buntu wobec zastanej rzeczywistości przy jednoczesnym uchwyceniu mechanizmu funkcjonowania wyobraźni „ja” lirycznego. Kwestia rekonfiguracji świadomości zostaje zestawiona z przeprowadzka, a więc z reorganizacją dotychczasowego życia: „Wynajęłam sobie przyszłość / i już od jutra muszę się wprowadzić / zmienić zamek po poprzednim lokatorze" ${ }^{40}$. W przywołanych wersach - konceptualnie nawiązujacych do poetyki nowofalowej ${ }^{41}$ chodzi oczywiście o zastapienie „mieszkania” poprzez „przyszłość” (podobnie, jak w przypadku „miasta” i „biosfery” czy „mebla” oraz „krajobrazu”). Intrygujący wydaje się także gest „zmiany zamka po poprzednim lokatorze”, który funkcjonuje mniej więcej w takim samym znaczeniu jak wers „Ktoś wielce nas oszukał" w interpretowanym wcześniej utworze Zawracajmy. W jednym i w drugim przypadku podmiot zostaje pozbawiony ontologicznej pewności, a fundamenty humanizmu wydają się mocno niestabilne (,i już od jutra muszę się wprowadzić”). W utworze pojawiają się również „toasty / weselne urodzinowe i pogrzebowe" 42 , odwołujące się do typowego dla kultury Zachodu temporalnego rytmu, zwiąanego z tradycyjnym pojmowaniem życia i śmierci. Przywołane „toasty” nie należą jednak do „biosfery”, w której osiedla się podmiot. Okrzepłe niegdyś pojęcia wymagają więc weryfikacji.

W perspektywie zagadnień posthumanistycznych pewne zastrzeżenia budzi izolacja, do której dąży podmiot. Zmiana punktu widzenia, czyli „nowy krajobraz”, niezbędna jest przecież, „żeby móc pisać i rozpoczać / życie samodzielne" ${ }^{43}$. Jak pogodzić zatem gest wycofania z szeroko rozumianym pojednaniem (ponownym powrotem) ${ }^{44}$ na poziomie egzystencjalnym? Należy pamiętać o zarysowanym wcześniej kontekście „traumy humanizmu”. Efektywna rewizja nie może obyć się bez rzetelnego namysłu nad poszczególnymi założeniami. Konkretyzując, jedno z możliwych odczytań wiersza Przyszłość dotyczy autorefleksji nad optymalną metodą przepracowywania

${ }^{40}$ E. Lipska, Przyszłość, [w:] Wiersze..., s. 22.

${ }^{41}$ Motywy „mieszkaniowe” w kontekście Nowej Fali skłaniają do przypomnienia ostatnich zdań recenzji Piatego zbioru wierszy autorstwa Stanisława Barańczaka: „Mowa była o kuchni językowej, pozostańmy więc przy tej metaforze: każdy wiersz poetki [Ewy Lipskiejprzyp. P.M.] przypomina jednopokojowe mieszkanie spółdzielcze, w którym kuchnia (wnęka kuchenna?) językowej techniki jest w całości widoczna z perspektywy izby mieszkalnej - zespołu znaczeń utworu. Ale to, że tej kuchni nie da się ukryć czy odgrodzić, jest również szansą poezji Lipskiej: zmusza jej twórczość do stałego samodoskonalenia się i ścisłej samokontroli”. Zob. S. Barańczak, „Nic mnie nie uratowato-żyje”, [w:] tegoż, Przed i po. Szkice o poezji krajowej przełomu lat siedemdziesiatych i osiemdziesiatych, Londyn 1988, s. 75.

${ }^{42}$ E. Lipska, Przyszłość, [w:] Wiersze..., s. 22.

${ }^{43}$ Tamże.

${ }^{44}$ Pojednanie (,reconciliaton”) stanowi jedna z konstytutywnych cech posthumanizmu według propozycji Francesci Ferrando. Zob. F. Ferrando, Posthumanism, Transhumanism, Antihumanism..., s. 29. 
wspomnianej „traumy”. W tym miejscu warto uruchomić metaforę autotematyczna - „żeby móc pisać” - która wydobywa z tego tekstu dodatkowe znaczenia. Właściwe przygotowania do praktykowania literatury (poezji) przynosza pomoc w procesie krystalizacji poglądów. Praca nad słowem (akt twórczy) utożsamiona zostaje z myśleniem o człowieku, a dokładniej $\mathrm{z}$ redefiniowaniem jego dotychczasowego statusu ${ }^{45}$. Świadomość podmiotu wydaje się mieć znamiona umysłu prometejskiego, opisywanego przez Ihaba Hassana. Amerykański badacz, który najprawdopodobniej jako pierwszy posłużył się pojęciem posthumanizmu w aktualnym znaczeniu ${ }^{46}$, wykorzystuje figurę Prometeusza jako odbicia umysłu zmagającego się (mind struggling) z „Wyobraźnią i Nauka, Mitem i Technologia, Językiem i Liczba”" W metaforze prometejskiej zaproponowanej przez Hassana dostrzec można odbicie opisywanej tu krytycznej świadomości, której ślady odnajduję także w puencie analizowanego wiersza Przyszłość: „Muszę sprawić sobie nowy krajobraz / To kosztowna rzecz" ${ }^{48}$. Pierwszy z przywołanych wersów stanowi powtórzenie czwartego wersu utworu i zdaje się podkreślać upór podmiotu w dążeniu do obranego, niełatwego (,to kosztowna rzecz”) celu.

Jednakże nadal istotne pozostaje pytanie o domniemane miejsce zamieszkania „ja”, a wszelka próba odpowiedzi sprowadza wątek przeprowadzki do roli metafory. Ewentualnego przemieszczenia nie sposób wówczas odczytywać w kategoriach fizycznych (czasowo-przestrzennych) - ma ono charakter wewnętrzny (świadomość podmiotu). Wspomniane tu pojęcie niematerialnego ruchu Lipska zdefiniuje później w poetycki sposób jako „lekturę istnienia”"99, posługując się istotną dla jej poezji figura ptaka. Pozostając w obrębie refleksji nad statusem człowieczeństwa, warto również zwrócić uwagę na inne teksty z tomu $J a$, chociażby na utwór tytułowy:

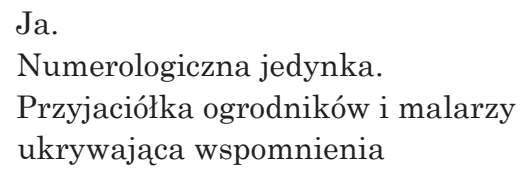

${ }^{45} \mathrm{Na}$ podobnej zasadzie zbudowany został chociażby wiersz Nad biurkiem z Czwartego zbioru wierszy, w którym czynność pisania zestawiona zostaje z chorobą nowotworowa: E. Lipska, Nad biurkiem, [w:] Czwarty zbiór wierszy, Warszawa 1974, s. 41.

${ }^{46}$ Pisząc o aktualnym znaczeniu mam tu na myśli przede wszystkim „zmianę paradygmatu myślenia o nas samych". Zob. M. Bakke, dz. cyt., s. 18.

${ }^{47}$ Odwołuję się tu bezpośrednio do zdania: „His mind is where Imagination and Science, Myth and Technology, Language and Number sometimes meet”, gdzie zaimek dzierżawczy „His” wskazuje oczywiście na Prometeusza. Zob. I. Hassan, Prometheus as Perfomer: Toward a Posthumanist Culture?, „The Georgia Review” 1977, vol. 31, nr 4 (Winter), s. 835.

${ }^{48}$ E. Lipska, Przyszłość, [w:] Wiersze..., s. 22.

${ }^{49}$ Zob. E. Lipska, Ruch, [w:] Ja..., s. 33. 
w magazynku broni palnej

wracam do wyjścia ${ }^{50}$.

W przywołanej strofoidzie najmocniej zdaje się wybrzmiewać zaimek osobowy - „Ja” - będący jednocześnie autonomicznym wersem. Podmiot opowiada o sobie bez zachwytu, a cechę konstytutywna jego samoświadomości stanowi gorycz oraz deziluzja: „numerologiczna jedynka”. Określenie własnej osobowości w kategoriach statystycznych ${ }^{51}$ może być wyrazem pesymistycznego, ale też trzeźwego przeświadczenia o nieuprzywilejowanej pozycji w świecie destabilizującym zastany porządek wartości ${ }^{52}$ - ,przyjaciółka ogrodników i malarzy" może sugerować wówczas zacieranie granic między naturą a kulturą. Lipska otwiera zresztą w tym samym tonie swoją książkę poetycką: „No i co z tego / że nasza planeta / objęta została rezerwacją"53. Cytowany wiersz ma w tym wypadku wymowny tytuł: Numer Jeden. „Jedynka” - także ta z utworu $J a$ - nie oznacza tu wcale bycia na czele, na pierwszym miejscu, przeciwnie, poprzez swoje ironiczne zabarwienie przypomina szyderczo o dawnym i, co ważniejsze, złudnym przeświadczeniu gatunku ludzkiego o własnej świetności ${ }^{54}$. Tekst Lipskiej, kwestionując człowieka jako istotę doskonała, wyraźnie koresponduje z egzystencjalistycznymi poglądami Sartre'a: „Humanizm można rozumieć jako teorię, która traktuje człowieka jako cel i wartość najwyższa. Taki humanizm występuje na przykład u Cocteau w opowiadaniu $W 80$ dni naokoło świata, kiedy jedna z występujących tam osób podczas przelotu samolotem ponad górami wygłasza zdanie: człowiek jest zdumiewający"55. Autor Przy drzwiach zamkniętych negatywnie ustosunkowuje się do przywołanego rozumienia humanizmu, określając go

${ }^{50}$ E. Lipska, Ja, [w:] Ja..., s. 9.

${ }^{51}$ Ten sam sposób metaforyzowania występuje w wierszu Wisławy Szymborskiej. Chodzi tu zwłaszcza o pierwszy wers Wyznań maszyny czytajacej - „Ja, Numer Trzy Plus Cztery Dzielone Przez Siedem": W. Szymborska, Wyznania maszyny czytajacej, [w:] Wystarczy, Kraków 2011, s. 7. W kontekście posthumanistycznym wspomina o tym utworze Iwona Gralewicz-Wolny: I. Gralewicz-Wolny, „Ubyliśmy zwierzętom. / Kto ubędzie nam”. Posthumanizm Wisławy Szymborskiej, [w:] tejże, W cudzystowie. O literaturze polskiej XX i XXI wieku, Katowice 2016, s. 133.

52 Jeden z nurtów filozofii posthumanistycznej (krytyczny posthumanizm) odrzuca myślenie oparte na schematycznych opozycjach, takich jak natura a kultura czy człowiek a zwierzę. Monika Bakke pisze o nim w kontekście prac Jill Didur oraz Neila Badmingtona. Zob. M. Bakke, dz. cyt., s. 21-22.

${ }^{53}$ E. Lipska, Numer jeden, [w:] Ja..., s. 5.

${ }^{54}$ Ten sam typ samoświadomości podmiotu poetyckiego pojawia się w utworze Tak samo: „Człowiek to taki zwykły człowiek: / jak pierwszy człowiek drugi człowiek. / Różnimy się jedynie tak bardzo podobnie / i przepadamy jak kamienie w wodę”. Zob. E. Lipska, Tak samo, [w:] Wiersze..., s. 10.

55 J.-P. Sartre, dz. cyt., s. 165. 
„absurdalnym” i niebezpiecznym ze względu na konsekwencje prowadzące do faszyzmu. Myśleniu o człowieku w wierszach Lipskiej można zatem przypisać cechy humanizmu nastawionego krytycznie względem własnych założeń i właśnie w tym znaczeniu poezja autorki Utopijnych trubadurów stanowi przykład poezji posthumanistycznej, czyli takiej, która stara się przepracować ograniczenia humanizmu.

W wierszu $J a$ równie istotne okazują się dalsze wersy, a wśród nich „ukrywane wspomnienia / w magazynku broni palnej”"56, które świadczyć mogą o zaburzonej kondycji psychicznej. Metafora militarna kazałaby sadzić, iż podmiot żyje w nieustannej gotowości, aby zmierzyć się z wypierana niegdyś przeszłością (,wracam do wyjścia”), a tym samym - przepracować traumę. Warto w tym miejscu przywołać - powiedziałbym nawet, że dość intrygująca - recenzję autorstwa Joanny Mueller „Ja” z jednej strony. Wprawdzie autorka Somnambóli fantomowych również podkreśla wage świadomości - „to nie tyle świat rozczarowuje [...] bardziej rozczarowuje świadomość" ${ }^{57}$ - ale czyni to w kontekście lingwistycznym, koncentrując się na zagadnieniu języka poetyckiego. Niemniej jedna z początkowych uwag zawartych w recenzji wydaje mi się szczególnie istotna dla rozważań znajdujących się w tym tekście:

Podpisać książkę w sposób tak zarazem trudny i prosty [Ja - przyp. P.M.] to niewątpliwie odwaga [...] w czasach, które są ukoronowaniem toczącej się bodaj od Kartezjusza i Kanta (choć oczywiście i wcześniej) dyskusji o podmiocie lub - za sprawą Nietzschego, Heideggera i Derridy - o zniknięciu przestarzałej kategorii „ja”. Ewa Lipska ustawia się poza tą dyskusja - przynajmniej takie chce sprawiać wrażenie. Bardziej niż rozbijanie atomu tożsamości (na wzór wciąż żywych, choć rzekomo „nieobecnych”, postmodernistów) lub rozpaczliwe poszukiwania obecności [...] interesuje Ewę Lipską ona sama, jakby postawiona naprzeciwko i odrębnie w stosunku do całego (literacko-filozoficznego) świata ${ }^{58}$.

Zgadzam się, że tom Lipskiej można by odczytywać w kontekście psychoanalitycznym, ale trudno przystać na zarzut (?) wyłączenia z „literacko-filozoficznej” polemiki na temat podmiotowości. Omawiane przeze mnie utwory ze zbioru Ja wpisują się w linię wytyczoną niegdyś przez wiersz Jesteśmy oraz pozostałe teksty z debiutanckiego tomu. Wspomniana linia koncentruje się na stopniowym podważaniu postulatów humanizmu związanych właśnie z koncepcją człowieka, prowadząc do zjawiska, które z powodzeniem nazwać można antropocentrycznym zachwianiem. Książka poetycka Lipskiej

\footnotetext{
${ }^{56}$ E. Lipska, Ja..., s. 9.

${ }^{57}$ J. Mueller, „Ja” z jednej strony, Odra” 2003, nr 11, s. 132.

${ }^{58}$ Tamże.
} 
z 2004 roku - przynajmniej częściowo - dotyczy więc refleksji „o zniknięciu przestarzałej kategorii ja". Dla mocniejszego ugruntowania moich uwag przytoczę fragmenty wiersza O sobie bez narzekań, wydanego w 2017 roku w zbiorze Pamięć operacyjna:

W moich genetycznych mutacjach

słychać Pieśń nad pieśniami.

Użala się nade mną moje DNA.

Dziedziczne choroby udaja

że się nie znaja. [...]

Migocze lampka: Boarding time.

To jeszcze nie mój lot ${ }^{59}$.

Cytowany tekst wpisuje się zarówno w refleksję tożsamościowa ${ }^{60}$ (która zapewne chętnie podjęłaby Mueller), jak i w proces kształtowania świadomości podmiotu poetyckiego (zasugerowana przeze mnie linia interpretacyjna), a także, nieco szerzej, w aktualne trendy myślenia o człowieku w ogóle. Podmiot tekstu O sobie bez narzekań w stanowczy sposób określa własna pozycje (czyni to w formie monologu lirycznego). W efekcie zanikaja wątpliwości i zawahania znane z utworu Ja. Przepracowywanie nadal istotny pozostaje aspekt niedokonany tej czynności - wspomnień (traumy) przynosi pozytywne rezultaty w postaci leksyki związanej z biotechnologią (,genetyczne mutacje”, „DNA”) oraz ze stechnicyzowanym światem (,Boarding time”). Podmiot bez problemu rejestruje dynamiczna rzeczywistość i nie chodzi tu już tylko o próbę wyjścia poza własne człowieczeństwo, poza prywatne „ja”, ale o samookreślenie w sieci rozmaitych powiązań z innymi elementami czy - jakby powiedział Bruno Latour ${ }^{61}$ aktorami tego świata.

${ }^{59}$ E. Lipska, O sobie bez narzekań, [w:] Pamięć operacyjna, Kraków 2017, s. 37-38.

${ }^{60} \mathrm{Na}$ spotkaniu autorskim, które odbyło się 10 października 2017 roku w siedzibie Wydawnictwa Literackiego w Krakowie, Lipska potwierdziła biograficzny kontekst wiersza. Omawiany utwór został przez poetkę przeczytany jako ostatni. Podkreślić należy, iż w trakcie wydarzenia większość tekstów czytała Anna Polony.

${ }^{61}$ Nawiązuję tu do Teorii Aktora-Sieci autorstwa Bruno Latoura ze względu na zapośredniczenie człowieka w wierszach Lipskiej przez - między innymi - obiekty technologiczne. Kondycja podmiotu w niektórych utworach często określana jest za pomocą różnorodnych urządzeń (od lornetki aż po czytnik linii papilarnych). Powstają zatem sieci (więzi), w których żaden z aktorów nie dominuje (nie ma mocy sprawczej na wyłączność). Konkretne realizacje poetyckie tego motywu składają się na spójną całość informującą o relacjach człowieka oraz technologii, która odgrywać mogłaby tym samym rolę „wielkiego” aktora. O koncepcji Latoura: K. Abriszewski, Teoria Aktora-Sieci Bruno Latoura, „Teksty Drugie” 2007, nr 1-2, s. 113-126. 
Humanistyczny dysonans (warunkowany przez posthumanistyczny potencjał humanizmu) obecny w utworach Lipskiej ulega swego rodzaju spiętrzeniu, a jego podwójne oblicze zaobserwować można w języku poetyckim. Nie sposób ukryć, że formująca się latami dykcja ${ }^{62}$ - oparta na lapidarności, paradoksie, oksymoronie czy zaburzeniach logiczno-składniowych ${ }^{63}$ - stanowi pułapkę, w którą uwrażliwiony posthumanistycznie podmiot wpada za każdym razem, gdy próbuje zawłaszczać otoczenie. Idzie tu o pułapkę antropomorfizacji, która czyha również na odbiorcę tych tekstów. Pozytywny aspekt wspomnianego zabiegu językowego ${ }^{64}$ zasugerowała całkiem niedawno Małgorzata Pieczara-Ślarzyńska: „Zwróćmy uwagę na antropomorfizację, jakiej poddawany jest świat, na jego ucieleśnienie, na mocy którego zyskuje on zindywidualizowane właściwości, unikalne niczym linie papilarne"65. Badaczka interpretuje utwór zamykający Czytnik linii papilarnych, czyli Świat. W moim artykule zajmuję stanowisko polemiczne, nie mogąc się zgodzić z powyższym odczytaniem. Jeśli tytułowy „świat” ma jakiekolwiek „zindywidualizowane właściwości”, to i tak stanowią one wynik subiektywnego projektowania rzeczywistości przez podmiot. Dla głębszego wyjaśnienia przywołam tu fragment rozważań Julii Fiedorczuk i Macieja Rosińskiego na temat metafory: „Biosemiotyczne badania nad metaforą uświadamiaja nam, że każda istota żywa, tak jak człowiek, dokonuje interpretacji rzeczywistości zgodnie z potrzebami wynikającymi z konkretnej, materialnej formy istnienia danego organizmu"66. Człowiek nie stanowi tu więc wyjątku (we wcześniejszych partiach wywodu autorzy wspominają o pracach Timothy'ego

${ }^{62}$ Krytyka chętnie wskazywała na konstytuująca się przez lata poetykę Ewy Lipskiej. Starczy tu wymienić chociażby Adama Poprawę (wymowny jest już sam tytuł recenzowanej przez niego Drzazgi - Lipska przez wieki się nie zmienia) czy Piotra Michałowskiego. Zob. A. Poprawa, Lipska przez wieki się nie zmienia, „Odra” 2006, R. 46, nr 7/8, s. 118-120; P. Michałowski, Czytanie siebie, „Odra” 2015, nr 9, s. 110-111.

${ }^{63}$ Przywołane określenia pozostaja charakterystyczne dla języka poetyckiego autorki Pomarańczy Newtona. Pisała o nich Marta Wyka, a ostatnio Magdalena Rabizo-Birek. Zob. M. Wyka, Język nad przepaścia, [w:] tejże, Punkty widzenia, Kraków 2000, s. 113; M. Rabizo-Birek, Ewy Lipskiej pótwiecze pisania. Laudacja dla laureatki Nagrody im. Juliana Tuwima za rok 2017, „Nowa Dekada Krakowska” 2018, nr 1 (35), s. 75.

${ }^{64}$ Nie jest to przypadek odosobniony. W kwietniowym numerze „Odry” z 2017 roku odnaleźć można dość obszerny tekst poświęcony głośnej książce Petera Wohllebena, Sekretne $\dot{z} y c i e$ drzew. Dla autorki artykułu notorycznie stosowane przez Wohllebena personifikacje nie stanowią większego problemu ani stylistycznego, ani metodologicznego (autorka wskazuje nawet na naukowość podejścia obranego przez niemieckiego leśnika). Zob. H. Schudy, Psychoanaliza lasu. „Sekretne życie drzew” Petera Wohllebena, „Odra” 2017, nr 4, s. 27-33.

${ }^{65}$ M. Pieczara-Ślarzyńska, Czytnik świata, „Twórczość” 2015, R. 71, nr 12, s. 108.

${ }^{66}$ Cyt. za: J. Fiedorczuk, M. Rosiński, Metafory w każdym życiu: fenomenologia, biosemiotyka, poezja, [w:] Po humanizmie. Od technokrytyki do animal studies, red. Z. Ładyga i J. Włodarczyk, Gdańsk 2015, s. 240. 
Mortona i jego przekonaniu o potrzebie antropomorfizowania ${ }^{67}$ ), ale w omawianym tekście Lipskiej ustawia się on w centrum i osłabia własne możliwości poznawcze, zacierając tym samym poznawany obiekt. Próba mówienia o świecie okazuje się narracją o ludzkości. Najważniejszy pozostaje więc fakt, że zarówno w kwestii języka poetyckiego (antropomorfizacja, personifikacja), jak i tematyki wiersza (wizja świata) bezdyskusyjnie dominuje optyka antropocentryczna ${ }^{68}$. O ile podmiot utworu rzeczywiście otwiera się na to co nie-ludzkie, o tyle czyni to z mocnej, ludzkiej perspektywy. Istnieje szereg tekstów Lipskiej, w których podmiot wydaje się osłabiony albo przynajmniej to osłabienie metaforyzuje (jak na przykład w wierszu Przyszłość).

Uchwycony przeze mnie dysonans koresponduje ponieką z uwagami Jana Wolskiego, który pisał o Lipskiej w kontekście postawy sceptycznej: „Uprawianie poezji to w przypadku autorki Ludzi dla poczatkujacych nieustajace poszukiwanie nowych form wypowiedzi, jakby badanie możliwości stylistyki, sprawdzanie nowych środków wyrazu"69. Powracają zatem wszelkie uwagi o nieufności i zmaganiu Lipskiej z językiem, sugerowane przykładowo przez Stanisława Barańczaka (recenzja Przechowalni ciemności) ${ }^{70}$ czy - jeszcze wcześniej - przez Jerzego Kwiatkowskiego (recenzja Czwartego zbioru wierszy) $)^{71}$. Poezji Lipskiej od samego początku towarzyszy zatem egzystencjalna niepewność, która znacząco wpływa na występujące w niektórych wierszach antropocentryczne zachwianie.

\section{Jesteśmy}

Zestawione w tym artykule wiersze składają się na linię interpretacyjna, która nie była dotąd eksploatowana przez badaczy twórczości Ewy Lipskiej. Fundamentalny dla moich rozważań pozostaje utwór Jesteśmy, wprowadzający odbiorcę na ścieżkę lekturową związaną z dyskursem posthumanistycznym. Najważniejszym tropem okazuje się wtedy osłabiony podmiot poetycki, a szczególnie interesująca jawi się jego świadomość o silnym potencjale

${ }^{67}$ Ten sam autor wskazuje jednak na eksperymentalny i laboratoryjny potencjał aktu twórczego.

${ }^{68}$ Nie oznacza to, że próbuję tu dyskredytować czy upraszczać wydźwięk bądź jakość artystyczną wiersza Lipskiej. Wskazuję jedynie na środek stylistyczny, który w języku poetyckim autorki Drzazgi umacnia ludzki podmiot, schodząc przy tym ze ścieżki posthumanistycznej interpretacji.

${ }^{69}$ J. Wolski, Ewa Lipska sceptyczna, [w:] „nic nie jest pewne”. O twórczości Ewy Lipskiej, red. A. Morawiec i B. Wolska, Łódź 2005, s. 9.

${ }^{70}$ Zob. S. Barańczak, Kwit z „Przechowalni ciemności”, [w:] tegoż, Przed i po..., s. 149-152.

${ }^{71}$ J. Kwiatkowski, Lipska po raz drugi, [w:] tegoż, Magia poezji (O poetach polskich XX wieku), Kraków 1995, s. 350-354. 
krytycznym. Rewizja założeń humanizmu dokonuje się zarówno na skali makro (status gatunku ludzkiego), jak i mikro (próba zrozumienia własnej pozycji względem innych bytów na świecie).

Dokonując ogólnej charakterystyki podmiotu, który wyłania się z analizowanych tekstów, zaobserwować można wiele punktów wspólnych z koncepcją podmiotowości zaproponowana przez Jolantę Brach-Czainę: począwszy od egzystencjalnej niepewności, przez specyficznie ukształtowaną dynamikę opartą między innymi na wewnętrznym ruchu w obrębie świadomości, aż po próbę odrzucenia opozycji między ludzkim a nie-ludzkim ${ }^{72}$.

W konkretnych realizacjach tekstowych odnaleźć można więc postawę harmonizująca z takimi stanowiskami filozoficznymi, jak posthumanizm krytyczny czy antyhumanizm. Nie oznacza to, że wiersze Ewy Lipskiej można identyfikować ze wszystkimi założeniami przywołanych prądów myślowych. Autorka Ludzi dla poczatkujacych nie jest przecież poetka całkowicie oderwaną od postmodernizmu czy humanizmu, a potwierdza to chociażby stosunek podmiotu do technologii, który oscyluje między technofilią a biokonserwatyzmem. Jednakże istnieje w tej twórczości potencjał pozwalający zrewidować, a w efekcie przekroczyć ramy ustanowione przez antropocentryzm, nawet jeśli owo przekroczenie dokonuje się momentami w niewielkim stopniu. Zawiązuje się wówczas możliwość rozmowy o posthumanistycznych aspektach poszczególnych utworów.

\section{BIBLIOGRAFIA}

Abriszewski K., Teoria Aktora-Sieci Bruno Latoura, „Teksty Drugie” 2007, nr 1-2, s. $113-126$.

Badmington N., Theorizing Posthumanism, „Cultural Critique” 2003, nr 53, s. 10-27.

Bakke M., Bio-transfiguracje. Sztuka i estetyka posthumanizmu, Poznań 2010.

Barańczak S., „Nic mnie nie uratowato - żyje”, [w:] tegoż, Przed i po. Szkice o poezji krajowej przełomu lat siedemdziesiatych i osiemdziesiatych, Londyn 1988, s. 72-75.

Barańczak S., Kwit z „przechowalni ciemności”, [w:] tegoż, Przed i po. Szkice o poezji krajowej przetomu lat siedemdziesiatych i osiemdziesiatych, Londyn 1988, s. 149-152.

Czapliński P., Bednarek J.B., Gostyński D., Literatura i jej natury, Poznań 2017.

Drzewucki J., Między intelektem a wyobraźnia, „Twórczość” 2017, nr 10 (863), s. 108-111.

Ferrando F., Posthumanism, Transhumanism, Antihumanism, Metahumanism and New Materialisms Differences and Relations, „Existenz. An International Journal in Philosophy, Religion, Politics, and the Arts" 2013, Volume 8, No 2, Fall, s. 26-32.

Ferrando F., Posthumanizm, transhumanizm, antyhumanizm, metahumanizm oraz nowy materializm. Różnice i relacje, „Rocznik Lubuski” 2016, t. 42, cz. 2, s. 13-26.

Fiedorczuk J., Cyborg w ogrodzie. Wprowadzenie do ekokrytyki, Gdańsk 2015.

${ }^{72}$ M. Bakke, dz. cyt., s. $85-87$. 
Fiedorczuk J., Rosiński M., Metafory w każdym życiu: fenomenologia, biosemiotyka, poezja, [w:] Po humanizmie. Od technokrytyki do animal studies, red. Z. Ładyga i J. Włodarczyk, Gdańsk 2015.

Gralewicz-Wolny I., „Ubyliśmy zwierzętom / Kto ubędzie nam”. Posthumanizm Wistawy Szymborskiej, [w:] tejże, W cudzystowie. O literaturze polskiej XX i XXI wieku, Katowice 2016, s. 117-133.

Hassan I., Prometheus as Performer: Toward a Posthumanist Culture?, „The Georgia Review” 1977, vol. 31, nr 4 (Winter), s. 830-850.

Houellebecq M., Możliwość wyspy, Warszawa 2015.

Jelewska A., Ekotopie: ekspansja technokultury, Poznań 2014.

Kołakowski L., Obecność mitu, Kraków 1981.

Kwiatkowski J., Lipska po raz drugi, w: tegoż, Magia poezji (O poetach polskich XX wieku), Kraków 1995, s. 350-354.

Lipska E., Białe truskawki, Kraków 2000.

Lipska E., Czwarty zbiór wierszy, Warszawa 1974.

Lipska E., Drugi zbiór wierszy, Warszawa 1970.

Lipska E., Ja, Kraków 2003.

Lipska E., Miasteczko Świat, Kraków 2007.

Lipska E., Nowy wybór wierszy, Kraków 2020.

Lipska E., Pamięć operacyjna, Kraków 2017.

Lipska E., Pęknięte oko czasu (droga pani Schubert...) / L'œil fêlé du temps (chère madame Schubert...), Kraków-Budapeszt 2017.

Lipska E., Wiersze, Warszawa 1967.

Lipska E., Wspólnicy zielonego wiatraczka, Warszawa 2007.

Lipska E., Życie zastępcze, Kraków 1998.

Lisowski K., Historie osobiste (o liryce Ewy Lipskiej), [w:] E. Lipska, Wspólnicy zielonego wiatraczka, Kraków 1996, s. 5-17.

Lyotard J.-F., Przepisać nowożytność, [w:] Postmodernizm a filozofia. Wybór tekstów, red. S. Czerniak, A. Szahaj, Warszawa 1996, s. 45-58.

Michałowski P., Czytanie siebie, „Odra” 2015, nr 9, s. 110-111.

Mueller J., „Ja” z jednej strony, „Odra” 2003, nr 11, s. 132-133.

„nic nie jest pewne”. O twórczości Ewy Lipskiej, red. A. Morawiec, B. Wolska, Łódź 2005.

Piech-Klikowicz A., „Patrzymy sobie w oczy...”. O twórczości Ewy Lipskiej, Kraków 2013.

Pieczara-Ślarzyńska M., Czytnik świata, „Twórczość” 2015, R. 71, nr 12, s. 106-108.

Po humanizmie. Od technokrytyki do animal studies, red. Z. Ładyga i J. Włodarczyk, Gdańsk 2015.

Poprawa A., Lipska przez wieki się nie zmienia, „Odra” 2006, R. 46, nr 7/8, s. 118-120.

Rabizo-Birek M., Ewy Lipskiej pótwiecze pisania. Laudacja dla laureatki Nagrody im. Juliana Tuwima za rok 2017, „Nowa Dekada Krakowska” 2018, nr 1 (35), s. 70-75.

Sartre J.-P., Problem bytu i nicości. Egzystencjalizm jest humanizmem, Warszawa 2001.

Schudy H., Psychoanaliza lasu. „Sekretne życie drzew” Petera Wohllebena, „Odra” 2017, nr 4, s. 27-33.

Skibski K., Antropologia wierszem. Język poetycki Ewy Lipskiej, Poznań 2008.

Szymborska W., Wystarczy, Kraków 2011.

Wyka M., Język nad przepaścia, [w:] tejże, Punkty widzenia, Kraków 2000, s. 112-120. 
Paweł Marciniak - doktor nauk humanistycznych w zakresie literaturoznawstwa. Rozprawę doktorską poświęcił twórczości Ewy Lipskiej. Interesuje się gatunkiem piosenki (zwłaszcza filiacjami między piosenka a poezja) oraz szeroko rozumianą intertekstualnościa. Publikował m.in. w „Poznańskich Studiach Polonistycznych”, „Czasie Kultury” oraz „Frazie”. Ma także wykształcenie romanistyczne. Na co dzień programuje w JavaScript, wykorzystując narzędzia cyfrowe do badań nad literaturą. ORCID: 00000002-9635-7375.

Paweł Marciniak - PhD in literature. His doctoral thesis was devoted to Ewa Lipska's writings. He is interested in the genre of song (especially the relations between song and poetry) and intertextuality. He has published in "Poznańskie Studia Polonistyczne", "Czas Kultury", and "Fraza", in additiont to other Polish literary reviews). Educated in Romance Philology. He codes in JavaScript and uses digital tools for his literary research. ORCID: 0000-0002-9635-7375. 
